International Journal of Linguistics, Literature and Culture
Available online at https://sloap.org/journals/index.php/ijllc/
Vol. 4, No. 4, July 2018, pages: $25 \sim 37$
ISSN: $2455-8028$
https://sloap.org/journals/index.php/ijllc/article/view/257

\title{
Religious Conversion towards Hindu Kaharingan to Christianity
}

Wayan Gepu ${ }^{\text {a }}$

I Ketut Suda ${ }^{\text {b }}$

I Made Suyasa $^{c}$

\section{Article history:}

Received: 10 February 2018

Revised: 25 June 2018

Approved: 3 July 2018

Published: 7 July 2018

Keywords:

Conversion;

Christianity;

Hindu Kaharingan;

\begin{abstract}
The mission theology brought to Asia generally and Central Kalimantan particularly turns out to be a spirit for Zending in conveying religious mission. The established theology must have been based on the church viewed that work and interfere in the global stage, achieving succession and living the gospel message to baptize and convert, or find a way to the weaker Kingdom of God. It becomes an elimination formulation for missionaries in an effort to Christianize people everywhere and one of them was in Pulang Pisau Regency, Central Kalimantan. The inhabitants of Central Kalimantan generally and Pulang Pisau Regency particularly, prior to the independence of Indonesian Republic 1945, indigenous people (Dayak) were adherents of the teachings of Kaharingan/Helu religion. After the entry of the Dutch in Central Kalimantan, carrying Christian teachings and following their mission religion, slowly many Hindu Kaharingan converted to Christianity. One affected by the missionaries in spreading their religious teachings was Pulang Pisau Regency. The religious conversion thereby Hindus Kaharingan in Pulang Pisau Regency that continues happening. It was feared the existence of Hindu Kaharingan diminishing wherein previously the population of Central Kalimantan and Pulang Pisau Regency particularly adhered to Helu/Kaharingan religion can be stated the majority but its existence now continues to decrease from their number due to be converted to Christianity. It could be affected and threatened existence of the customs that were typical of Hindu Kaharingan.
\end{abstract}

2455-8028 ${ }^{\circledR}$ Copyright 2018. The Author. This is an open-access article under the CC BY-SA license (https://creativecommons.org/licenses/by-sa/4.0/) All rights reserved.

Author correspondence:

Wayan Gepu,

Institute of Hindu Negeri Tampung Penyang Palangka Raya, Indonesia

Email address: wayan.gepu@gmail.com

\footnotetext{
a Institute of Hindu Negeri Tampung Penyang Palangka Raya, Indonesia

${ }^{\mathrm{b}}$ University of Hindu Indonesia

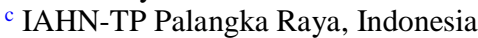




\section{Introduction}

Indonesia is a country consists of the different religions adopted by its citizens. If Indonesian previously recognized five emergence types belief or religions, unlike according to the globalization era and government leadership, providing opportunities for increasing or for the new religion in Indonesia. Respecting the leadership succession and bureaucratic existence reforms has provided a conducive climate for the growth and development for the new religion in the country. The evidence since Gus Dur's leadership, Confucianism has begun to be recognized become an official religion by the government. The globalization era as well as brought many changes that have implications for social-cultural caste life in the society, including Indonesian people. The globalization influence of the science and technology also significant influence on the order of the religious social life for the society. It is evident, the most people especially teenagers who are more interested in technological equipment, especially information technology owned rather than associating and playing with their friends.

Religion is a form of human belief towards a thing that is in principle supernatural and always accompanies human life in a vast living space. It has values for their life individually and in relation to people's lives. Religion psychologically serves as the intrinsic motive (inner self) and extrinsic (external) human motive itself. The motives that encourage religious beliefs have amazing power and difficult to be matched by non-religious beliefs. Due to religion has a unique supernatural property, therefore, it is difficult to be defined properly, precisely and satisfactorily (Agus, 2005: 4).

Religion is normatively too far from the desire to exert emphasis, among intern and religion. Due to prioritizing religion also teaches etiquette and advocates morality. It shows that religion is an important source of values and moral norms in the various practices of human life, therefore, in Indonesia freedom of religion is guaranteed by the law, even religious people are given freedom in carrying out various religious practices, especially, concerning the worship implementation. However, the recent diversity phenomenon suggests a tendency to sharpen religious issues, especially, regarding the pressures experienced by traditional religions from mainstream groups. The traditional religion has been shown to play an important role in human life from centuries ago. The traditional religion has been used as a guide of behavior in realizing the social collective consciousness. Due to the traditional religion, regularity, system balance, and structure can be maintained (Main, 2013: 1).

Religion is an important aspect for the human life, or it is a universal phenomenon. It is found in every society. The existence has existed since prehistoric times, therefore, running the religion teachings is a right and duty for all human beings on this earth. Certainly, in performing or carrying out religious teachings embraced by all human beings on this earth. The force is absence or pressure from any party. Many religious converts or are known as religious conversion, due to a lack of religious understanding and beliefs that have been practiced. The transfer of one has beliefs as well as due to what makes belief so far. It has not been felt to provide comfort and tranquility, and thirst for something that can provide inner peace. The need for religion is the right of all human beings on this earth. The religion gives guidance or noble teachings about how human beings should do, act, live life according to norms in individual life, and social life.

Religious conversion actually has lasted from along ago until now. One of the religious conversion happened to Hindu Kaharingan to Christianity in Central Kalimantan. This is due before Kaharingan integrated with Hindu religion in 1980, Dayak people adhered to Kaharingan teachings considered as belief flows, and not a religion many Kaharingan people feel that not wearing. It is worshiping jinns, demons, and politicism. This is voiced by the missionaries who at that time, incessantly influenced the Kaharingan people to convert their beliefs, with new beliefs they spread. The Central Kalimantan region is an area with a multicultural population consists of various tribes and religious teachings, which interact with other religious societies, in their daily lives. The area in Central Kalimantan whose people convert to Christianity is in Pulang Pisau Regency.

Pulang Pisau Regency is a region with a population or society consists of various religious adherents for the various tribes. In carrying out their daily life, the social interaction one adherent to other religion, and living in a mutual respect for each other, the occurrence unlike conversions is interpreted to affect the traditional customs existence related to rituals Hindu Kaharingan nuanced will be lost due to abandonment. Based on the above background thereby the study can be formulated: (1) how Hindu Kaharingan convert to Christianity in Pulang Pisau Regency? (2) how the religious conversion implication of Hindu Kaharingan to Christianity in Pulang Pisau Regency? (3) how does the effort conducted by Hindu Kaharingan people not convert to Christianity in Pulang Pisau Regency? 


\section{Research Methods}

The present study applied qualitative methods. All data is analyzed descriptively. It is used a paraphrase to explain, elaborate, and explore regarding the phenomenon belonging. The conclusion is the last remarked based on the previously description.

\section{Results and Analysis}

Discussion

3.1 The factors occurred religious conversion of Hindu Kaharingan to Christianity in Pulang Pisau Regency:

a) Weak understanding towards Hindu Kaharingan teachings

Religion is the foundation. It is firm for humans in living their life in the world. The strong understanding of religious teachings, surely negative influences, whose nature plunges humans into immoral acts, can be avoided. A well understanding of religious doctrine, strong, and profound, any unfavorable temptations are certainly inevitable. The mature religious teaching is a powerful weapon. If the mind becomes determinant decision making to do something. It is included theology understanding, ritual, and ethics in a religion. The importance of understanding and deepening religious teachings is very needed by all human beings. It is very important along with the shifting values and mindset of current mankind. It prioritizes actions based on the ratio rather than taste. It affirms that the urgency for humanity, to be able to deepen and understand the religion teachings owned, through a theology understanding, philosophy, and rituals that exist in the religious elements.

Hindus Kaharingan is a weakness of some understanding of religious teachings. It would be easy to seduce, instigated in order to convert to another religion (Christian). It is a contrast to Christianity, wherein its people matured in understanding their religious teachings. Christianity even refines its theology through a social science perspective. Therefore, Christians understanding of their religion is well established (Surpi, in Donder, 2011: 125). Based on a strong and mature understanding of religious teachings, it is surely very profitable when Christians dialogue with other religious people and used as a very powerful weapon to fend off various seduction, persuasion. Therefore, it is not easily tempted to change beliefs.

Related to the religious conversion, Hindu Kaharingan to Christianity in Pulang Pisau Regency, Maslow in motivation theory wherein the human hierarchy needs one is self-authorization. Due to the weak understanding of Hindu Kaharingan with religious teachings, making them difficult in facing various temptations, challenges, and even incitement from other parties (missionaries). The dialogue related to belief (religion), they are not able to explore the ability possessed. The weak understanding about religious teachings that have become very difficult to be able to actualize all capabilities owned. It becomes one of the motivations of conversion of Hindu Kaharingan in Pulang Pisau Regency.

Related to the above statement, in the constellation of the religious sociology theory developed by Durkheim in functionalist perspective seems to be relevance currently. Since Durkheim theory emphasized the religious function. For Durkheim, the main function of religion is to promote social cohesion and solidarity. The high element of them will lead to strong social control. Every individual has a sense of belonging to their society. Therefore, it doubles both in improving self-control and social control. The individual has a high sense of belonging both to the society and the religion adopted. The individual will also feel obligated to maintain their belief (Haryanto 2015: 23-24).

A weak understanding for the teachings of their religion will be a contradiction to the people themselves, in dispelling the challenges and temptations of other religious parties, with various efforts to propaganda, invite, and incite, and influence someone to switch their beliefs. The religion is a belief that comes from the divine teachings revealed by God, to give a speech to a human in their life in the world. Thus, to achieve physical/temporal, spiritual/heavenly happiness. The purpose of life is important to know and be understood carefully. Due to it will be the main foundation of mankind in various activities. The deep understanding of the religious teachings as a form of the ideal mankind needs.

The religious conversion occurred in Pulang Pisau regency of Central Kalimantan. Hindu Kaharingan converts their religion to Christianity. Due to it still has not understood the teachings both theologically/tattwa, ethics, and ceremonies. It is very influential for the individual and become one of the people motivations to change their

Gepu, W., Suda, I. K., \& Suyasa, I. M. (2018). Religious conversion towards Hindu Kaharingan to Christianity. International Journal of Linguistics, Literature and Culture, 4(4), 25-37. https://doi.org/10.21744/ijllc.v4n4.257 
beliefs. The lack of religious understanding adopted, allowing people will feel difficult when dialogue with others. Whether the dialogue is formal or informal. Especially, at this time, the human life has been mixed with other people in the social environment. Therefore, the debate regards religion can not be avoided. To allow the dialogue takes place, not infrequently belief that adherents questioned by other people.

It is not uncommon due to dialogue and debate to make the religious beliefs loss their adherents. The religious conversion in Pulang Pisau Regency to Christianity, due to weak understanding adopted to make someone a confidence crisis for their belief so far. The trust crisis was due to a lack of understanding of the religious superficial teachings. Thus, there are people from other religions asking about existence, as well as questioning the truth of religious teachings, will have difficulty to explain it. Even though answered, but the answer is very shallow. In the end, someone offers and promises something capable of giving salvation, blessings, and even heaven. It is possible to be affected by the promised mastering a new religion.

\section{b) Educational factors}

Education is essentially an effort to pass on values. It will be helper and mankind determinant in life, and at the same time to improve the fate and mankind civilization. Without education, it is believed that human beings today are not much different from the human beings generations in the past. If it is compared to humans, have been left behind by both the life quality and the empowerment processes. It extremely can be stated back and forth or good/bad civilization or society will be determined how the education is lived by the society itself. Due to education can be defined as a changing individual behavior process, of course, in this case, is a change towards a better aim.

Education is a humane act. It is born from the association between adults and immature people of affinity living. The educating act is conducted of adults either consciously or unconsciously for the human values. Unlike the actions due to immature persons to mature by having humanitarian values and living according to those values. The maturity is a goal to be achieved through the educational action (Hasbullah 2011: 5). According to Damsar (2010: 8) described education is a process of changing attitudes and behavior of a person or group of people in an effort to mature the human through education: (1) people experience changes in attitude and behavior, (2) people process into adults, and (3) the process of maturation is conducted through the efforts of teaching and training.

Education/knowledge has an enormous influence. Someone is faced with various life phenomena for their dynamically moving world, where the intellectual level, enough to have influence and play a significant role when one will make a decision. Having sufficient knowledge will make people want to live more meaningful. It is not only for the soul, fellow, and even meaningful with the universe. Unlike revealing by Weber (2012: 324), described the scholars trying in various ways a case is infinite in number, in order to bestow on life with a profound meaning, therefore, meet unity with their self-based on their fellow dean with the cosmos.

Mastering sufficient knowledge/education must be one of the weapons to break a doubt sense, to the decisive actions is taken. The knowledge will open the thinking horizon to a person. It is faced with issues that require well thinking when external influences occurred. The established knowledge/education has the one possesses is capable of doubts removing when confronted with the issues. The knowledge will be used as a weapon to decide the feelings of these doubts. As stated in the Bhagavad Gita, Adhiyaya IV Sloka 41 and 42 describes:

Yoga-sannyasta-karmanam jnana-sanchinna-samsayam

Atmavantam na karmani albadhanti dhananjaya.

Translation:

Working activities will not fetter those who have released all activities with Yoga, which has destroyed all their doubts with wisdom and who always rely on themself, O Dhananjaya (Arjuna) (Bhagavad Gita, IV: 42).

\section{Tasmad ajnana hri-stham jnanasinatmanah}

Chittvainam samsayam yogam astisthottistha Bharata

Translation:

Therefore, after cutting the hesitations with the knowledge sword (wisdom) in the heart that comes from ignorance. Take shelter in Yoga and rise, O Bharata (Arjuna) (Bhagavad Gita, IV: 42)

Mastering knowledge/science will make someone to take an action/decision more carefully and full of thoroughness. Therefore, the decisions taken no doubt will be useful and even useful for themselves and for others. The conversion of Hindu Kaharingan beliefs to Christianity is greatly influenced by the lack of knowledge about 
the religion they possess. If there is no religious education in school, it turns out enough influence someone can convert religion. It happens due to at home already not to get the religious knowledge. They do not have confidence in the basic. Therefore, the religious conversion happened for some Hindu Kaharingan people to Christianity in Pulang Pisau Regency, due to lack of knowledge owned, both general academic knowledge, and religious knowledge. Due to the low level of education owned, thus, if they are faced with influences from outside or propaganda, which endeavors with various efforts, and persuades with promises, ease in the new practice (Christian)/religious teachings.

\section{c) Family factors}

The family is a group consists of father, mother, and their children still dependent on them and at least an adult male bound by marriage or blood relations. It serves to strengthen social solidarity, cultural value-investing, economic cooperation, and the fulfillment of psychological needs, unlike the need for love, caring for each other, protecting, and expelling the loneliness sense.

Hartomo, et al (2011: 79) described that the family is the most important primary group in society. Inculcating religious values in children is very important in the family environment. Wherein, it is intended to strengthen the sense of love of the religion is owned, thus, more loving and animating and imprinted stronger in the deep of heart. The true religious knowledge has been educated early on the family environment, by providing guidance on religious knowledge. Due to the most opportunities and time to get knowledge, especially, related to the beliefs are in the family environment. Therefore, the stronger beliefs and beliefs should be one of the strongholds for the people to defend their religion (belief) has been practiced for a long time ago. Respecting the family support, the religious conversion should be avoided. The life in the family environment can also be one cause of the religious conversion.

The influence of the family occurred religious conversion from Hindus Kaharingan to Christianity in Pulang Pisau Regency, due to the family environment is less/not enough to provide well education about Hindu Kaharingan teachings. Therefore, the religious knowledge possessed shallow/weak, whether it concerns the ritual, ethics, and tattwa/theology. Thus, if there are person/group of people who try to persuade and seduce with various propaganda, and give promise with various ease in carrying out religious teachings which are new, then gradually. It does not close the possibility will be easily affected, and eventually change beliefs. The life of Dayak people in Pulang Pisau Regency, in one family or one residence, has different beliefs or religions. It will affect one of the family members and can make a confidence change, less strong beliefs owned.

\section{d) Economic factors}

Human in their life in this world can not be separated from what is called the life needs. To fulfill their needs continuously is dynamic without being able to avoid, requires financial or economic support to make life well. Related to the above description, Mayer (2000) described that the questioning economic issue needs and the satisfaction of human needs, which is a human need for goods and services that nature and type very diverse in an unlimited amount. Furthermore, according to Mayer economic issues, the existence of a fact that is unequal since human needs for goods and services are infinite, that is why humans in their lives are always faced with disappointment and uncertainty.

The difficulty in meeting the basic needs to be alive is a factor in religious conversion. Maslow (1980), stated that in the hierarchy of the human needs explained, physiological needs, clothes, food, boards, as the basic human need in living their life in the world. If the basic physiological needs, difficult to fulfill due to the low economy will be the motivation for a person to do or do something that gives peace to him. Unlike the perpetrators of religious conversion, Hindu Kaharingan to Christianity in the Pulang Pisau Regency. The economic issue will be so complicated/difficult for those with low incomes. Therefore, to meet the needs of life is very hard. Regarding the weakness of their financial/economy seems to be one factor due to the social change for Hindu Kaharingan in Pulang Pisau Regency, and become a motivation to convert their religion. It was revealed in an interview to informants related to factors due to the religious conversion. The informants stated due to economic difficulties in their family life. The people decided to convert to another religion (Christian). It is undeniable that the important role of the economy in the mankind welfare.

Gepu, W., Suda, I. K., \& Suyasa, I. M. (2018). Religious conversion towards Hindu Kaharingan to Christianity. International Journal of Linguistics, Literature and Culture, 4(4), 25-37. https://doi.org/10.21744/ijllc.v4n4.257 
e) Marriage factor

Marriage factor is enough to hold a very important role in the religious conversion from Hindu Kaharingan in Pulang Pisau Regency. It is surely very interesting to be discussed and explored more deeply. The reason is due to many perpetrators of religious conversion occur through marriage. It is the union of two very principled things between the masculine and feminine elements. It is a bet on the ideology of belief (religion), which leads through the religious conversion fundamentally.

The religious conversion due to marriage in Pulang Pisau Regency occurred due to the love and honey. It was in accordance with the motivation theory of Maslow (1981). Wherein, the hierarchy of human needs, Maslow describes love and compassion necessary through deep interpersonal relationships. It is reflected in the needs of various social groups. Related to the religious conversion of Hindu Kaharingan to Christianity in Pulang Pisau Regency. The factor of love and honey became one of the motivations of some people to convert their religion. A deep and true love, capable of succumbing to the person ideology, it was happened of Hindu Kaharingan converts to Christianity, caused by a love. It seems to have a significant role in the religious conversion. Love is full of sacrifices, a form of ideology of love and great affection, therefore, defeating other ideology. It is true the religious conversion based on loving deeply and strongly. It abandons its belief (Hindu Kaharingan) and turns to a new belief (Christianity).

\section{f) Environmental residence factors}

Human is a living being that can not live alone due to wherever humans live, settle, or stay, surely always mingle with other. In this case, it can be stated that human is social i.e., surviving their life will always contact or interact with others. Fitriyah, et al (2014: 231) described that social interaction can be interpreted as dynamic social relations. The relationship is among individual to other individuals. Social interaction is the main requirement of the social activities. It is the social relationships dynamically, concerning the relationship among individuals, groups of people, as well as people attraction with human groups.

Related to the above description the environmental factors as a place to live, is one factor of the religious conversion of Hindu Kaharingan to Christianity in Pulang Pisau Regency. It happens due to most of the people or Hindu Kaharingan are in the midst of the confluence of other religious people. It is more the majority in terms of quantity. It is surely running daily lives, always touch or interact with people who do not have the same belief. In interaction, many things that may happen, both general and specific problems, even to the beliefs issue can be discussed. Thus, it occurs mutual influence among individual or one group with another group.

\section{g) Factor of still weak or less intense education}

Religion unlike a form of human belief, it will be accompanied in a wide scope of life. It has values for human life as a person and in relation to social life. The religious conversion happened to Hindu Kaharingan people, to Christianity in Pulang Pisau Regency. It is due to several factors, as described in the above description. The lack of guidance to Hindu Kaharingan causing the religious conversion in Central Kalimantan and Pulang Pisau Regency particularly. It can happen to anyone in this part of the world, does not look old or young. The conversion of beliefs or religious for Hindu Kaharingan is very unfortunate because the existence of Hindu Kaharingan people who initially the majority in terms of numbers will be reduced even become a minority. increase understanding for their religious teachings should continue to be encouraged by all parties. It is conducted, therefore, the people become stronger and stronger with the teachings of religion. So that the guidance to society or religious people should continuity is done, thus, people will be stronger with their religion or belief. Surpi (2011: 152) described the weakness of education for Hindu Kaharingan resulted in some Hindus, especially, in Abianbase converting to Christianity. The religious conversion implications of Hindu Kaharingan to Christianity in Pulang Pisau Regency included:

\section{1) Implication towards individual}

Human is individual beings and also social, as individuals due to the essence of humans have a life of the privacy (person) that no one else can enter in it. There are joints of life that no one can enter and play a role in their personal life. Setiadi (2006: 63), stated that the individual comes from the word individuum. It means 
undivided. In individual English comes from the word in and divided. The word in one contains not understanding, while divided means become more than one.

Doing religious conversion is an option that has been taken. Therefore, it is for the perpetrators of individual religious conversion, will try to keep the relationship with the family, and new environment, mingle, and social contact/social action, in order to be united in the social environment. It is the family and social environment. Weber in Lubis (2015: 53), stated that a social action is an act of understanding society. The distinctive features of social relationships are those meant to those who take part in them. There are three forms of struggle, society, and cooperation. For religious conversion from Hindu Kaharingan to Christianity, indirectly requires a struggle in facing challenges, due to the new environment, of course, requires adjustment, with the aim of being well received in the new social environment.

\section{2) Implication towards family}

The family is the smallest unit of society and consists of the head of the family and some people are gathered and live in a place under a roof in an interdependence state. A family is a group of women, dependent children, and at least an adult male related to the marriage or blood relationships. Surviving a life, with a new belief, increasing family members will be a challenge that must be faced. For the perpetrators of religious conversion, due to building togetherness in a difference of belief must be put forwarding in order to avoid the contradictions and disputes to the family members in-laws or from the families concerned (the perpetrators of the conversion) itself. The religious conversion of Hindu Kaharingan people, it is unfortunate, but all of that back to the personal and related to the decisions in determining the way of life and life. The perceived implications for religious converts from Hindu Kaharingan to Christianity to the family, as well as not influential in the sense of living in the family is harmonious, peaceful, and peaceful. Harmony in family life is maintained, due to Dayak people generally hold firm local tradition known as Kula. Kula is a family value, as a Dayak ethnic group in Central Kalimantan, and in Pulang Pisau Regency particularly. Kula (kinship) is an emotional bond and feeling as a family, with peace, love, and harmony.

\section{3) Implication towards customs}

Human life in this world can not be separated from the prevailing habits and attached to the area or region. The habits are called by custom. The Indonesian nation is known to have a diverse cultural life. It is reflected in the life of Indonesian people everywhere, in the territory of the Republic of Indonesia. Ethnologically, the custom comes from Arabic meaning "usual", thus, it can be stated that custom is as a repetitive act, then becomes a habit and still respected people.

Dayak customs generally and Hindu Kaharingan particularly can not be separated by religious rituals/ceremonies. Unlike Hindu Kaharingan in Pulang Pisau Regency recognize some customs that are part of tradition or custom which is always implemented, and preserved. Custom is the ancestor's inheritance who they have religious meanings and values. It is related to religion/ritual, solidarity, and ethics. The relationship between customs and ritual can be divided into two kinds i.e., customs related to life and death. The custom habits related to the life among others included marriage ceremony, nyaki dirit, mamalas bidan, nahunan, pantan, pakanan sahur, balian mambuhul, nyadiri, manyanggar lewu, manenung, and others. The custom related to death included ceremonies for cremation, mangarak hinau, tantulak ambun rutas matei, and tiwah.

The implications of religious conversion from Hindu Kaharingan to Christianity related to the customs (ceremonies) of the death ceremony. Related to the ritual of death is no longer practiced, unlike Balian Ambun Rutas Matei and tiwah, those who have converted their belief from Hindu Kaharingan to Christianity is no longer do the customs (tradition) that is related to the death. While, the customs (traditions) in the social life in the society, related to the social solidarity is still carried out, done, it is seen from mutual respect to each other, visit each other, stay in touch with the moment of their respective religious day, custom (tradition) gotongroyong (handep), well preserved, meaning that despite the change of faith still uphold the tradition of mutual help/help to help each other.

\section{4) Implication towards social environment}

Being individual and social human in the social environment will not be separated by social processes. For the perpetrators of religious conversion from Hindu Kaharingan to Christianity in Pulang Pisau Regency, in Central Kalimantan. It certainly will not be separated from others, intersect, touch, around the neighborhood where they lived. It allows social contact the social environment. The social relation is an adjustment process

Gepu, W., Suda, I. K., \& Suyasa, I. M. (2018). Religious conversion towards Hindu Kaharingan to Christianity. International Journal of Linguistics, Literature and Culture, 4(4), 25-37. https://doi.org/10.21744/ijllc.v4n4.257 
of the social values in the social life. The social process is also characterized by interaction and mutual understanding, communicate, and social relationships dynamically in solving a problem in the social life.

The living environment is the essence of the human beings due to in the fact the empirical individual is a unity in social integration. Shani (1987) describes social integration not only with the criteria of assembly or unity in the physical sense but also at the same time developing the attitude of solidarity and human emotion is a foundation rather than a degree of harmony within a group or society. Therefore, the integration is connected individuals to other individuals in the social environment in the society. Being ethical, respecting one another, and upholding the guidelines of life and becoming penyang hinje simpei paturung huba tamburak, as a pilot in living life and life in a multicultural society, strived to be maintained and upheld by the perpetrators of religious conversion in Pulang Pisau Regency from Hindu Kaharingan to Christianity always maintaining harmonious relationships in their social environment, thus, avoiding conflicts, disputes, resulting in potential horizontal conflict, and can harm the harmonious relationship in the life of the larger society. It is what the perpetrators of religious conversion are conducting and doing, therefore, they remain harmonious, peaceful, safe, peaceful with the social environment in which they are despite the change of belief.

\section{5) Implication towards ritual system}

Religious human life will not be easily separated from a series of activities related to rituals/ceremonies. The rituals are a series of activities that are carried out primarily for symbolic purposes. It is performed on the basis of a religion or can also be based on the traditions of certain societies and activities in rituals are something that is set, determined, implemented, and should not be arbitrarily in the implementation process. The religious life in most adherents will not be separated from the ritual. Due to the ritual is part of grouping human life that is difficult to separate. The rituals are performed for a specific purpose, as they can fulfill their religious or ideals, fulfill their spiritual or emotional needs.

Agus (2005: 95-95), in the religious book for the human life, the ritual is a belief in the sacred and demands special treatment, There is a treatment way of something sacred. There is a religious ceremony, in the sacred face. The ceremony and special treatment can not be understood economically and rationally. Related to offerings and religious services are usually not understood for economic reasons, rational, and pragmatic. The religious conversion from Hindu Kaharingan to Christianity will surely have some implications related to the ritual in Kaharingan Hindu teachings. Due to after converting the religion, inevitably have to follow the teachings and teachings of the new religion chosen. Understandably, the doctrine of the new religion is not the same as what was believed and became a prior belief. Due to basically every religion has different teachings, ordinances, and aims. Regarding conversion of Hindu Kaharingan religion to Christianity in Pulang Pisau Regency from some informants convey their insights after embracing Christianity, they no longer do/perform the rituals that have always been practiced when before converting.

\subsection{The efforts avoid a religious conversion}

It is forwarding the efforts conducted to avoid Hindu Kaharingan people do not convert to Christianity included:

\section{a) Assembly effort}

The number and type of Hindu institutions in Indonesia is not a lot. It is partly due to there are not too many religious sects (streams) as living and fertile bodies, unlike India. However, the view of the type is quite diverse due to the existence of religious institutions are highly influenced the various purposes, such as religious illumination, religious ceremonies, sacred art, religious education, social, and punia (donation). The goal has given birth to a different typology of one institution with another. These institutions take the foundation form. The differences of the tribes, traditions, and cultures also helped support belonging diversity and uniqueness of religious institutions, e.g., customary institutions in Bali, Java, Kalimantan, persantian (Balinese song) institutions, and others.

The center assembly of Hindu Kaharingan is routinely conducting training for the young. As a concern form of Hindu Kaharingan people who are in the regency, sub-district, and village, always willing to attend. If Hindu Kaharingan people in the regency, sub-district, and village hold Hindu Kaharingan religious activities, e.g., there are rituals of tiwah/menyanggar lewu, dharma shanti nyepi, the central board is always present, either as an invitation or when asked to deliver pandehen (religious speaker). The presence of administrators of religious 
institutions, in this case, MB-AHK, as a concern form of Hindu Kaharingan people anywhere, not least in Pulang Pisau Regency. The presence of the central committee, of course, as one of coordination form, communication, built, well maintained, ranging from the regency, district, and village levels.

\section{b) Through the festival of Tandak Intan Kaharingan}

The Christianity is entered in the Central Kalimantan region that was carried and propagated for the missionaries (Zending), affects some of Hindu Kaharingan converts their religion. The subject occurs due to the incessant missionaries, in carrying out its mission of spreading the broadcast of the Christianity teachings. Its spread almost covers most of Central Kalimantan. One of the regions, it was affected by the spread of Christian broadcasting, conducted by missionaries is in Pulang Pisau Regency. It resulted in some Hindu Kaharingan people converting to Christianity. Aware of the matter, various efforts are made for all religious leaders, society leaders of Hindu Kaharingan, in anticipation of Hindu Kaharingan avoid or even do not convert religion, even though it is a private right of the people.

The various efforts were made by all religious leaders, instructors, and religious teachers, as described above in intensifying the understanding of Hindu Kaharingan teachings to their people. The aforementioned through pandehen (lecturer/spiritual leader), both when people carry out basarah (praying) in the hall (Hindu Kaharingan worship place), as well as at the time family basarah. The aim is for Hindu Kaharingan more stable with religious teachings that are believed for this. Therefore, it is not easily deterred by various persuasion types, which is always waged by the religion spreaders (missionary) who always tried to influence Hindu Kaharingan for this.

\section{c) Improving social understanding of Hindu Kaharingan teachings}

The Christianity is entered in the Central Kalimantan region generally and Pulang Pisau particularly distributed or carried by missionaries in spreading the gospel. It has a significant impact on the quantity of Hindu Kaharingan. Wherein, before the missionaries, the quantity of Hindu Kaharingan presence in Central Kalimantan, especially, in Pulang Pisauregency can be stated almost the most population adheres to Hindu Kaharingan or better known as helu religion. Riwut (2003: 536), in the book entitled Maneser Panatau Tatu Hiang, declared the original religion of the Dayak tribe in Central Kalimantan for the first was the religion of Helu, which means first. Koentjaraningrat (2004), described that the indigenous religion in Central Kalimantan is Kaharingan. The term Kaharingan was used after World War II when the natives of Central Kalimantan arose an awareness of their own cultural personality, as well as a strong desire to revive the Indigenous Dayak culture (Koentjaraningrat, 2004: 135).

Wijaya (2007), in the book entitled Serat Salib Dalam Lintas Bali stated that if Catholic mission in the area of Bali Tsang To Hang provides an understanding that the religious conversion from Hinduism to Catholicism, has changed their codes of conduct, releasing bad habits that are irrelevant to Catholic life elves. However, it has not yet provided a psychological figure. Since it was never mentioned after embracing their new religion, thus, completely forgetting the ingrained belief tradition in the ancestral spirits, leaks or teachings of Karmaphala (2007: 5).

Improving Hindu Kaharingan people understanding for their religious teachings is very important to do wherever not least in Pulang Pisau Regency. Giving enlightenment, through dharmawacana, dharmatula, and dharma santi. It is important to understand the religious teachings, especially, the three basic Hinduism frameworks, included Tattwa/theology/Brahmawidya, ethics/susila, ritual/ceremony. Due to the three religious framework is the foundation or basis of religious teachings that must be understood. Therefore, if people have been able to instill its value then the faith will be strong and sturdy, thus, it is not easily affected by various incitement and persuasion from any party.

\section{d) Through formal and non-formal education}

Education for human life is very important due to well education able to survive the life continues to dynamic every time. Having good knowledge will be able to guide every human being in this world, in determining steps to achieve a better life. The efforts made to prevent the religious conversion of Hindu Kaharingan to Christianity in Pulang Pisau Regency, Central Kalimantan, it is better to know in advance the meaning of education and understanding of formal education. Education comes from the Greek language, i.e., paedagogie defines guidance given to the child. In English, education comes from word to educate that is nurturing, educating. Thus, education

Gepu, W., Suda, I. K., \& Suyasa, I. M. (2018). Religious conversion towards Hindu Kaharingan to Christianity. International Journal of Linguistics, Literature and Culture, 4(4), 25-37. https://doi.org/10.21744/ijllc.v4n4.257 
can be interpreted as a process of guidance and advice that is done someone continuously to the students to achieve educational goals (Afifudin, 2013: 13).

Teaching religious value to the students in the formal education environment will have a very good and positive impact. Due to considering not all children get religious knowledge in the family environment. Therefore, formal education is expected to gain religious knowledge. Therefore, it is a good knowledge of religion, animating, and loving, honey, religion owned, thus, not easily melted with persuasion from any party still keep and love with confidence. Embedding religious values of teachings to learners in the environment of the formal education. It is very helpful to learners. Since the religious education in formal education is very important for fostering and perfecting the growth of the student personality. The religious education has two important aspects. The first aspect of religious education is addressed to the soul or the personal formation. In this case, the children are given an awareness of the existence of the God then get adhered to the God and away for all prohibitions. The second aspect of religious education is addressed to the mind. Due to the belief in God will not be perfect, if the content of the God teachings is not known well, i.e., the students must know what is allowed, and what is forbidden in the religious teachings.

Furthermore, through non-formal education, education in Indonesia has two school system education. Outschool education consists of informal and non-formal education. It is called formal education began to be known in Indonesia since the Dutch colonial era. The formal and non-formal education is structurally organized, whereas, informal education is not organized, education does not occur in the indicated field of programmed teaching and learning as well as formal and non-formal education e.g., education in the family, lectures (Sanari Faisal, 1981: 4849).

Through coaching for children of the early ages, through Sunday school as part of non-formal education, is thereby needed by Hindu Kaharingan society in Pulang Pisau Regency, regarding the data was obtained in the field, from eight sub-districts, none or have pasraman/school weekly legitimation. However, the administrators of the sub-districts assembly, the group did not despair. They coordinated to Hindu religious teachers, to invite the children to explore and study Hindu Kaharingan religion in their respective sub-districts and villages. Giving the importance of instilling religious values to children from an early age, and school-aged children. The same thing also conveyed by the board of assembly in Central Kahayan area, according to Amey (interview, August 26, 2016) stated that, the guidance of coaching children ranging from early childhood to children who have good school at elementary, junior high, outside of school hours or informal education, is necessary. Due to the religious lessons learned in school or in the formal education are quite limited. Thus, to build a mentality and character of children and instill religious values and noble values of Hindu Kaharingan teachings. It takes non-formal education through Sunday school.

\section{e) Family effort}

According to Sobur (2013: 248), stated that family is the smallest social institution of the society. The definition of family shows that the family is part of society. The part determines the whole of society. In a society once known, it is almost everyone lives related to the network of obligations and family rights called role relationships (role relations). A person is awakened to the existence of the role relationship due to the socialization process has been going on since childhood, a process in which they learn to know what family members want, which ultimately raises awareness of the desired truth. In every family, the family is a social institution that is very important for a life. The family is the first and most important education for the child. Due to in the family, the child begins their growth. It is physical as well as spiritual growth development.

Educating children about an especially early childhood, the family environment of Hindu Kaharingan in Pulang Pisauregency has an important role in the effort to build and shape the children characteristics. Due to the forming essence of the character, the child from an early age would be very useful in shaping the psyche of the child. As elaborated by Elmubarok (2013: 102), character building is the process of carving or painting the soul in such a way that the "shaped/formed" is unique, interesting, and different or distinguishable from others. Unlike a letter in an alphabet that is never the same from one to another. Therefore, the character can be distinguished from each other. For what is meant here is to form the character of the child, can be started by introducing the teachings about religion and how to perform religious obligations. It is certainly family, in this case, the parents began to involve them in religious activities, e.g., invite them to pray, although the child has not understood the meaning and sense, but at least the children will imitate or follow what they see and pay attention to. Due to the essence of early childhood has a tendency to imitate what they see. 
It is thereby the family role, especially, the mother is very important in determining the children character in the future. Due to she has patience in nurturing and educating them. She also arranges that organize and encourage the atmosphere in the house. She becomes the key to shaping the personality and character of her children and gives a reprimand if the child does a mistake and also gives praise if her child can do something well. While, the father acts as a supervisor, straightening, and refining the process.

\section{Conclusion}

The religious conversion is able to be happening to anyone, anywhere, and anytime unlike Hindu Kaharingan in Pulang Pisau Regency, Central Kalimantan. In the past, it is almost the major population is Helu (Kaharingan). However, the time goes entry of Christianity, with their religious mission, begins to influence of Hindu Kaharingan with its propaganda and seduction, influences the people (Hindu Kaharingan) to convert become Christianity, and basically what they do (missionaries) are quite successful in making Hindu Kaharingan people leave their religion and convert to Christianity. There are several factors that cause included the weak understanding of Hindu Kaharingan people with their religion, economic factors, marriage, education, living environment, and family factors. The religious Conversion due to the existence of Hindu Kaharingan in Pulang Pisau Regency is reduced in quantity.

Conflict of interest statement and funding sources

The authors declared that they have no competing interest. The study was financed by Wayan Gepu.

\section{Statement of authorship}

The authors have a responsibility for the conception and design of the study. The authors have approved the final article.

\section{Acknowledgments}

The author would like to thank Prof. Dr. I Ketut Suda, M.Si. and Dr. I Made Suyasa, MAP., M.Si, for their valuable time and advice as well as giving a spirit and support in completing the article.

Gepu, W., Suda, I. K., \& Suyasa, I. M. (2018). Religious conversion towards Hindu Kaharingan to Christianity. International Journal of Linguistics, Literature and Culture, 4(4), 25-37. 


\section{References}

Artadi, I. K. (2004). Nilai Makna dan Martabat Kebudayaan. Denpasar: Sinay.

Aryadharma, N. K. S. (2011). Membedah Kasus Konversi Agama Di Bali.

Bakker, J. W. M. (1984). Pustaka Filsafat Filsafat Kebudayaan, Sebuah Pengantar. Kanisius.

Basrowi, S. (2002). Metode Penelitian kualitatif perspektif mikro. Surabaya: Insan Cendekian.

Boland, B. J. (1992). Intisari iman kristen. BPK Gunung Mulia.

Bungin, B. (2007). Penelitian Kualitatif (Edisi Kedua): Komunikasi.

Damsar, A. (2010). Pengantar Sosiologi Politik. Jakarta: Kencana Prenada.

Dhavamony, M. (1995). Fenomenologi agama. Kanisius.

El Arbaoui, F. Z. (2018). Feminist dystopian consciousness in margaret atwood's the handmaid's tale. International Journal of Linguistics, Literature and Culture (IJLLC), 4(4), 1-9.

Elmubarok, Z., \& Hidayat, D. R. (2008). Membumikan pendidikan nilai: Mengumpulkan yang terserak, Menyambung yang terputus, dan Menyatukan yang Tercerai. Alfabeta.

Eriyanto, A. F. (2002). Konstruksi. Ideologi dan Politik Media, Yogyakarta: LKIS.

Feist, J., \& Feist, G. J. (2010). Teori kepribadian. Jakarta: Salemba Humanika, 219-376.

Gaya. (2016). Intergritas Kepercayaan Kaharingan ke Dalam Agama Hindu di Kota Palangka Raya.Denpasar : disertasi IHDN Denpasar.

Ginaya, G. (2018). The Balinese calendar system: From its epistemological perspective to axiological practices. International Journal of Linguistics, Literature and Culture (IJLLC), 4(3), 24-37.

Hasbullah, O. P. (2007). Kebijakan Otonomi Daerah Dan Implikasinya Terhadap Penyelenggaraan Pendidikan. PT Raja Grafindo Persada: Jakarta.

Haviland, A., Hufford, W., Bennett, G., \& Bird, D. (2006). U.S. Patent No. 7,041,254. Washington, DC: U.S. Patent and Trademark Office.

Kahmad, D., \& Cuanda, C. (2000). Sosiologi agama. Remaja Rosdakarya.

Pusat, B. P. (1995). Undang-Undang Dasar, Pedoman Penghayatan dan Pengamalan Pancasila, Garis-Garis Besar Haluan Negara.

Rakhmat, J. (2013). Psikologi agama: sebuah pengantar. Mizan Pustaka.

Saliman, A. W., \& Wulandari, T. Persepsi dan Sikap Mahasiswa Terhadap Pendidikan Karakter di Prodi Pendidikan IPS UNY. SOCIA: Jurnal Ilmu-Ilmu Sosial, 10(2).

Siregar, S. (2013). Metode penelitian kuantitatif dilengkapi dengan perbandingan perhitungan manual \& SPSS. Jakarta: Kencana Prenada Media Group.

Suarda, I. W., Yadnyawati, I. A. G., \& Suda, I. K. (2018). Portrait of Hindu religious teacher performance certified educator in junior high schools Denpasar. International Research Journal of Management, IT and Social Sciences (IRJMIS), 5(3), 53-61.

Sutopo, H. B. (2002). Metodologi penelitian kualitatif.

Suyanto, B. (2012). Sutinah,(2005) Metode Penelitian Sosial, Berbagai AlternatifPendekatan. Jakarta: Kencana Prenada Media Group.

Walgito, B., \& Walgito, B. (2004). Pengantar psikologi umum. 


\section{Biography of Authors}

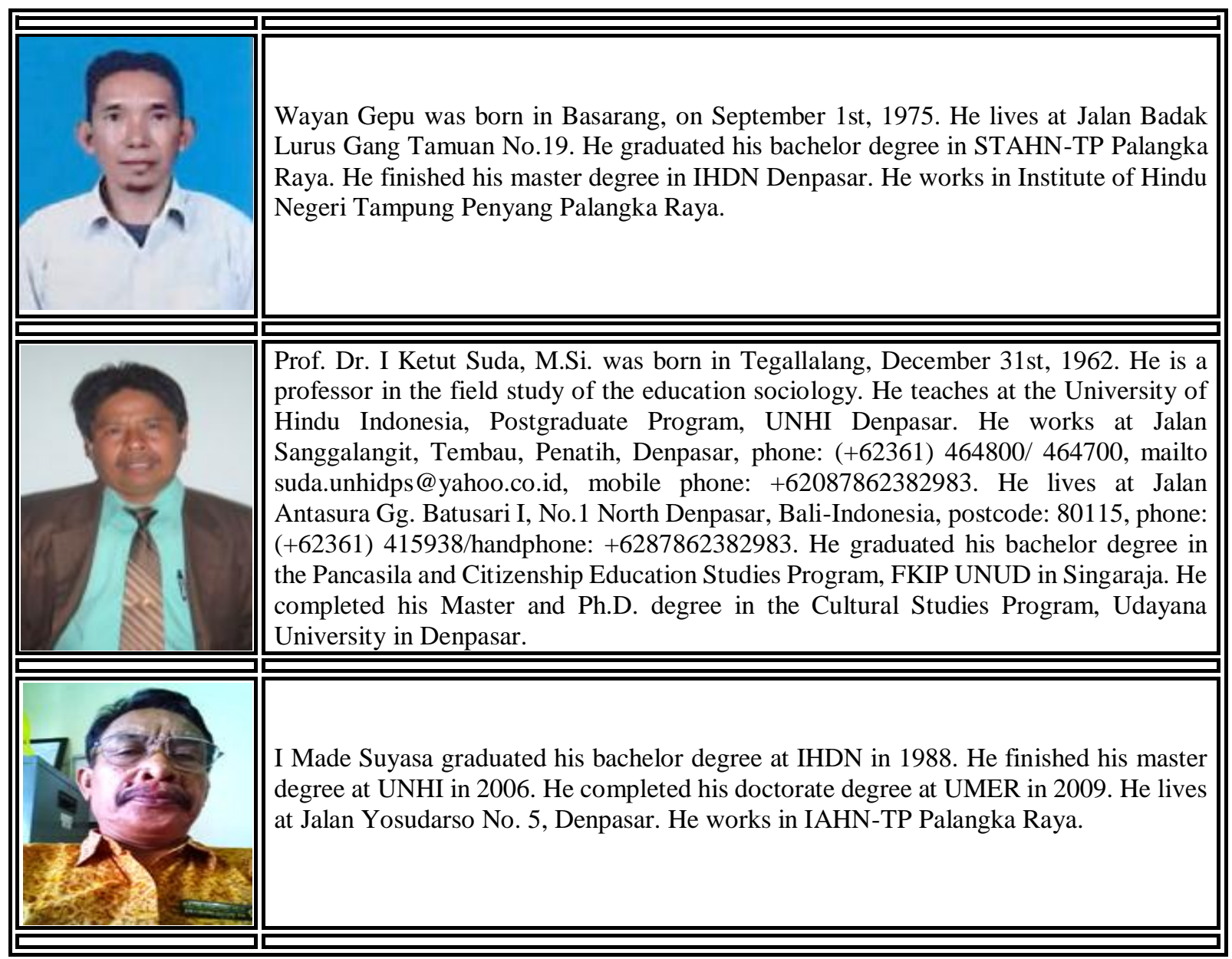

Gepu, W., Suda, I. K., \& Suyasa, I. M. (2018). Religious conversion towards Hindu Kaharingan to Christianity. International Journal of Linguistics, Literature and Culture, 4(4), 25-37. https://doi.org/10.21744/ijllc.v4n4.257 